\title{
A MINIMUM-COST AND ENVIRONMENTALLY-SAFE PROGRAM OF HERBICIDE MAINTENANCE FOR INDIANA ROADSIDES
}

DECEMBER 1973 - NUMBER 32

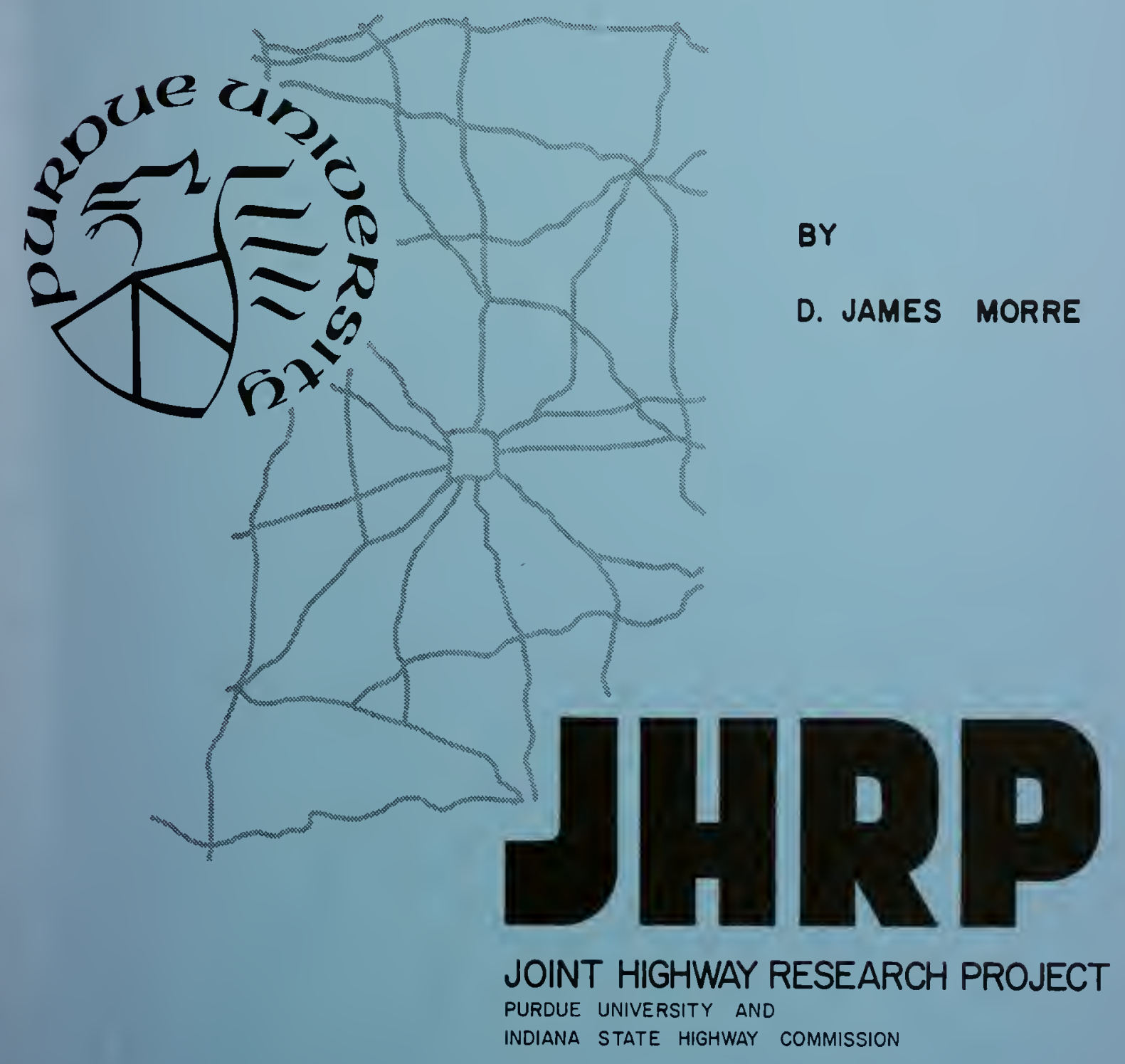


Technical Paper

A MINIMUM-COST AND ENVIRONMENTALLY-SAFE PROGRAM OF HERBICIDE MAINTENANCE FOR INDIANA ROADSIDES*

by

D. James Morre

Department of Botany and Plant Pathology

Purdue University

Joint Highway Research Project

Project: C-36-48F

File: $\quad 9-5-6$

Prepared as Part of an Investigation

Conducted by

Joint Highway Research Project

Engineering Experiment Station

Purdue University

In cooperation with the

Indiana State Highway Commission

and

U. S. Department of Transportation

Federal Highway Administration

The contents of this report reflect the views of the author who is responsible for the facts and the accuracy of the data presented here in. The contents do not necessarily reflect the official views or policies of the Federal Highway Administration. This report does not constitute a standard, specification, or regulation.

Purdue University

West Lafayette, Indiana

February 19,1974 


\section{A MINIMUM-COST AND ENVIRONMENTALLY-SAFE PROGRAM OF HERBICIDE MAINTENANCE FOR INDIANA ROADSIDES*}

T0: J. F. McLaughlin, Director Joint Highway Research Project

FROM: H. L. Michael, Associate Director Joint Highway Research Project
February 19, 1974

Project: $\quad C-36-48 \mathrm{~F}$

File: $\quad 9-5-6$

The attached Technical Paper is submitted on the HPR, Part II Research Study "Low-Cost Maintenance Program for Indiana Roadsides". It has been authored by Dr. D. James Morre, Principle Investigator on the Study, and is titled "A Minimum-Cost and Environmentally-Safe Program of Herbicide Maintenance for Indiana Roadsides".

The paper has been accepted for presentation at the Annual Meeting of the Highway Research Board in Washington D. C. in January 1974 and is also planned for publication by that group.

The paper is a breif summary of the program developed for the current HPR Study and which is actively being applied in Indiana on an experimental basis. The objectives, content and early findings of the program are presented along with anticipated savings from the program in Indiana.

The paper is submitted for approval of publication and will also be forwarded to ISHC and FHWA for similar approval. Notification of ISHC and FHWA of plans for presentation and approval thereof have been previously forwarded.

Respectfully submitted,

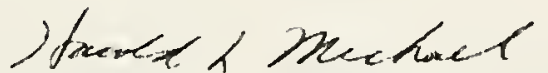

Harold L. Michael

Associate Director

$H L M: m w$
$C C:$ W. L. Dolch
R. H. Harrell
C. F. Scholer
R. L. Eskew
M. L. Hayes
G. D. Gibson
C. W. Lovell
M. B. Scott
W. H. Goetz
G. W. Marks
J. A. Spooner
M. J. Gutzwiller
R. D. Miles
N. W. Steinkamp
G. K. Hallock
G. T. Satterly
H. R. J. Walsh
E. J. Yoder 
Digitized by the Internet Archive in 2011 with funding from

LYRASIS members and Sloan Foundation; Indiana Department of Transportation 
A MINIMUM-COST AND ENVIRONMENTALLY-SAFE PROGRAM OF HERBICIDE MAINTENANCE FOR INDIANA ROADSIDES*

D. James Morré

Department of Botany and Plant Pathology, Purdue Unfversity, Lafayette, IN 47907

\section{ABSTRACT}

The purpose of this study was to design a minimum-cost maintenance program for vegetation control along Indiana roadsides. Mechanical and chemical methods were combined to maintain healthy turf at low cost. A 3-year (enviromentallysafe) spraying rotation in combination with mowing was recommended and implemented. It provides a maximum-benefit, low-cost maintenance program for the State of Indiana with cost savings in excess of $\$ 200,000$ annually.

With the development of the Interstate system, the management of turfed roadsides is an increasingly important function of the Highway Department. Divided lanes, median strips, and broad rights-of-way are an integral part of the modern highway, and the management of turfed roadsides is no longer a minor consideration of roadside maintenance. Healthy roadside turf prevents soll erosion, protects adjacent cropland from invading weeds, and provides features of beauty, safety, and convenfence.

Rights-of-ways are designed for safety and convenfence. They must be maintained if the safety and convenience features are to be preserved.

What happens when roadsides are not maintained in a turfed or semfturfed condition? Even with careful landscaping and restricted mowing, areas whlch are not maintained revert to native vegetation. Tall weeds and wild grass kfll turf by shading only to die back during the winter to leave patches of bare soil open to erosion (Fig. 1). In as little as one year, tree seedlings and root sprouts may become established on unmaintained rights-of-way. After a number of years, these sprouts become bruah and eventually trees. Brush obscures vision to add a hazardous condition to an otherwise safe highway. If sight distances are reduced by vegetation below minimum specifications, the state is liable to litigation in the case of accidents. Trees immediately adjacent to major highway present an obvious safety hazard. Such trees and brush must be removed at considerable expense and the turf reestablished to prevent additional erosion. The costs of tree and brush removal and reestablishment of turf exceed the costs of modest annual maintenance programs.

Turf stabilizes the soil and prevents erosion. Sediment from soil erosion is the major pollutant of Midwestern waterways; the problem would only increase in severity if roadside rights-of-ways were not maintained.

Along the Interstate System and major State Highways of Ind Iana and throughout most of the Midwest, the roadsides are already turfed, principally bluegrass, and mostly free of trees between the edge of the shoulder and the fence-1ine except for steep banks and certain scenic areas (Fig. 2). The soil 1s mostly of high fertillty and much of the roadside borders on cultivated agricultural land of high productivity. Of major concern in protecting both the established roadside turf and the adjacent crop land is the control of weeds and brush. The control methods must be effective, inexpensive, and not deleterious to either the environment or to adjacent crops.

* Work sponsored in part by Joint Highway Research Project, Purdue University and Indiana State Highway Commission Project C-36-48C "Research in Roadside Development and Maintenance, Part III. Chemical Weed Control" and an award from the Office of Water Resources. Purdue University AES Journa1 Paper No. 5230. 
The program recommended and implemented for the State of Indiana involves combined herbicide and mowing treatments. Environmental-and crop-safety are insured by use of non-toxic amine formulations of herbicides and late fall and early spring applications. Effectiveness and low cost are provided by a 3 -year rotation in comblnation with reduced mowing.

Applications of herbicides in the fall prevent growth of weeds the following spring and summer and provide maximum safety to the environment.--Implementation of results obtained under the Joint Highway Research Project at Purdue Universitestablished the effectiveness of fall applications of herbicides to control problem weeds along roadsides (1, Figs. 1-4). Applications are made from September 1 until the first killing frost (Table 1 ).

\section{TABLE I}

A PROGRAM OF ALTERNATING FALL AND SPRING APPLICATIONS OF HERBICIDE IMPLEMENTED IN THE SPRAYING-BY-CONTRACT PROGRAM FOR THE STATE OF INDIANA

Material: 2,4-D amine form concentrate containing at least 4 pounds of acid equivalent per gallon. Ester formulations of 2,4-D are not used due to possible environmental hazards.

Rate: The materlal was recommended to be mixed at the rate of 2 gallons of 2,4-D concentrate to 100 gallons of water. The mixture is applied at the rate of 40 gallons per acre.

Schedule of application:

a) Fall: September 1 to first killing frost.

b) Spring: March 15 to April 30

As the first killing frost approaches, hard-to-kill perennial weeds move all available materials into the underground parts of the plants. Herbicides applied at this time reach the underground plant parts through translocation activity when these parts are most susceptible to the killing action of the herbicide $(1,2)$. Dandelion, plantain, buckhorn, creeping charlie, milkweeds, Canadian thistle, dock, and other problem roadside perennials are among the weeds susceptible to fall applications of herbicides.

Plants with a biennial growth habit are also controlled by fall applications of herbicides. Wild parsnip and wild carrot are examples of especially troublesome roadside weeds with biennial growth habits (Fig. 6). Plants germinate in the spring and summer to overwinter as small plants with a whorl of leaves about grass height in mowed turf. The following spring, the plants produce a flowering stalk up to 5 feet high which is unsightly, obstructs vision, k11ls turf by shading, and produces abundant seed to ensure reinfestation (Fig. 6). Herbicide applications in spring or summer are ineffective in killing the plants or even in preventing production of viable seed since the plants grow rapidly in early spring. They are frequently in full flower by May 15. Fall applications of herbicide give complete control of these weeds for up to 3 years (Fig. 6) while spring applications of twice the amount of herbicide do not provide even single season control.

Winter annuals are a third category of weeds controlled by fall applications of herbicides. Winter annuals germinate in the fall, enter a rosette stage in which they overwinter, and flower in early spring. Examples include henbit, shepard's purse, yellow rocket, and most of the wild mustards. These plants are killed in the fall as they germinate through pre-emergence action of the herbicides.

The only category of plants which escapes a fall application of herbicide is the summer annuals such as pigweed, ragweed, lambsquarter, and velvet leaf. These plants are common weeds of crop lands but seldom invade healthy turf. They are encountered only infrequently along Indiana's roadsides. 


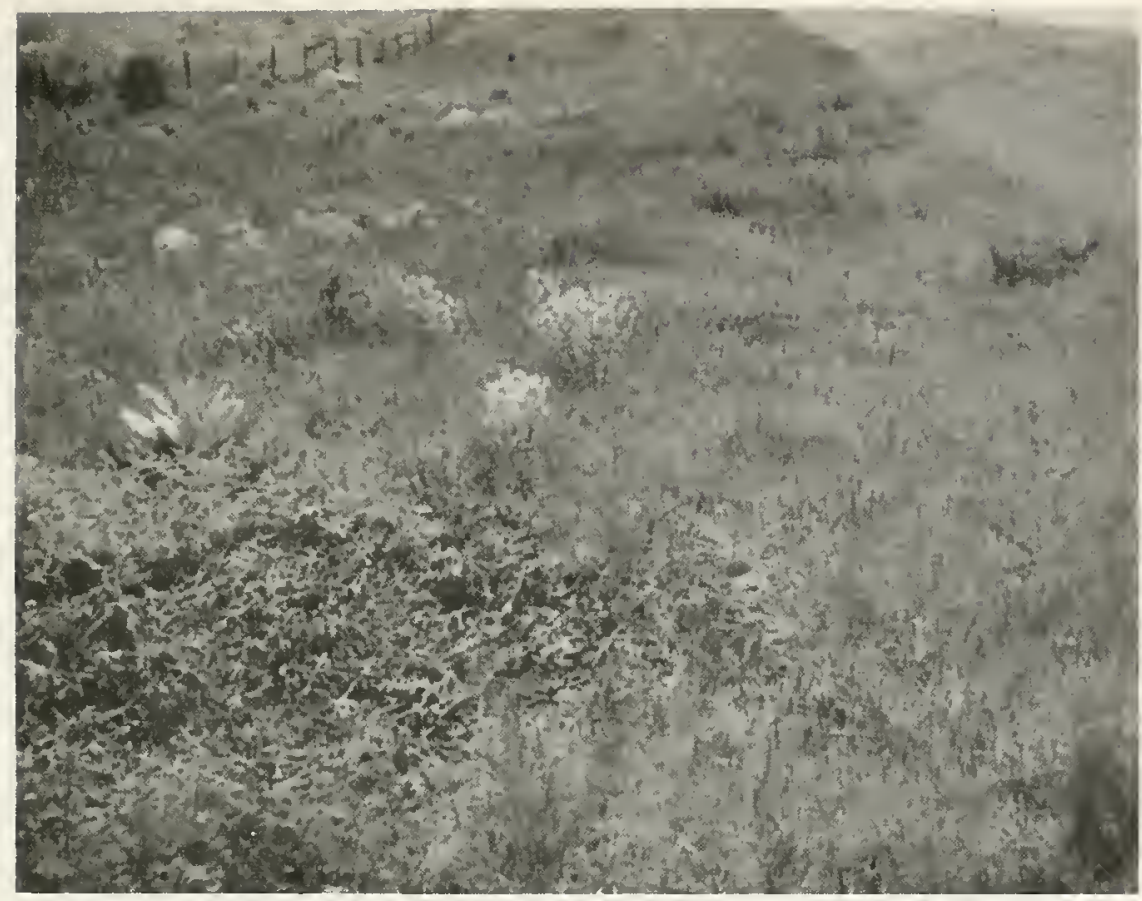

Figure 1. Unsprayed section of I-69 near the Indiana-Michigan border. Ta11 reeds and grass have smothered out the turf leaving patches of bare soil subject to erosion. Photographed June 2, 1973.

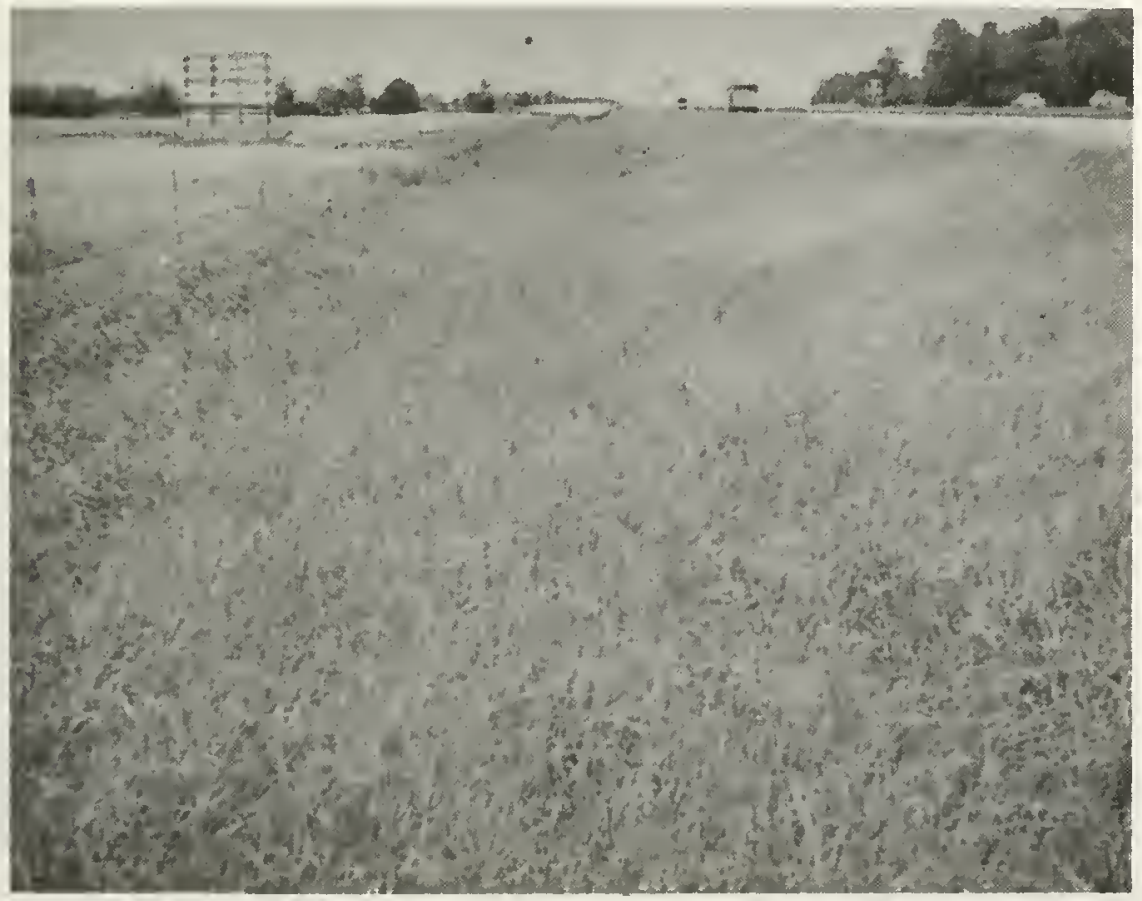

Figure 2. Sprayed section of I-69 near the Indiana-Michigan border. This portion received the fall-spring 2,4-D application cycle in the 1972-73 season in the Spraying Program by Contract (Table I). The roadside is essentially weed-free. Photographed June 2, 1973. 


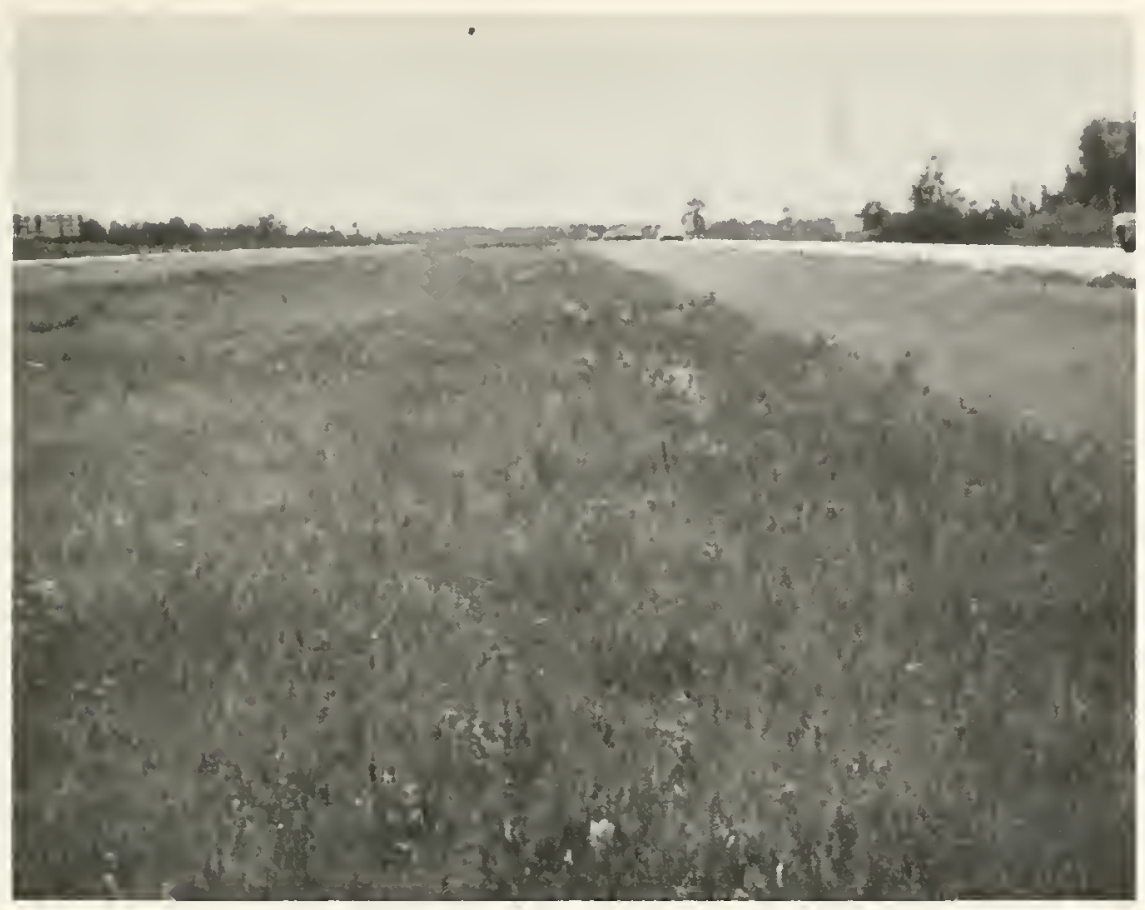

Figure 3. Unsprayed median of I-69 near the Indiana-Michigan border. Numerous weeds are seen in the foreground. Photographed June 2, 1973.

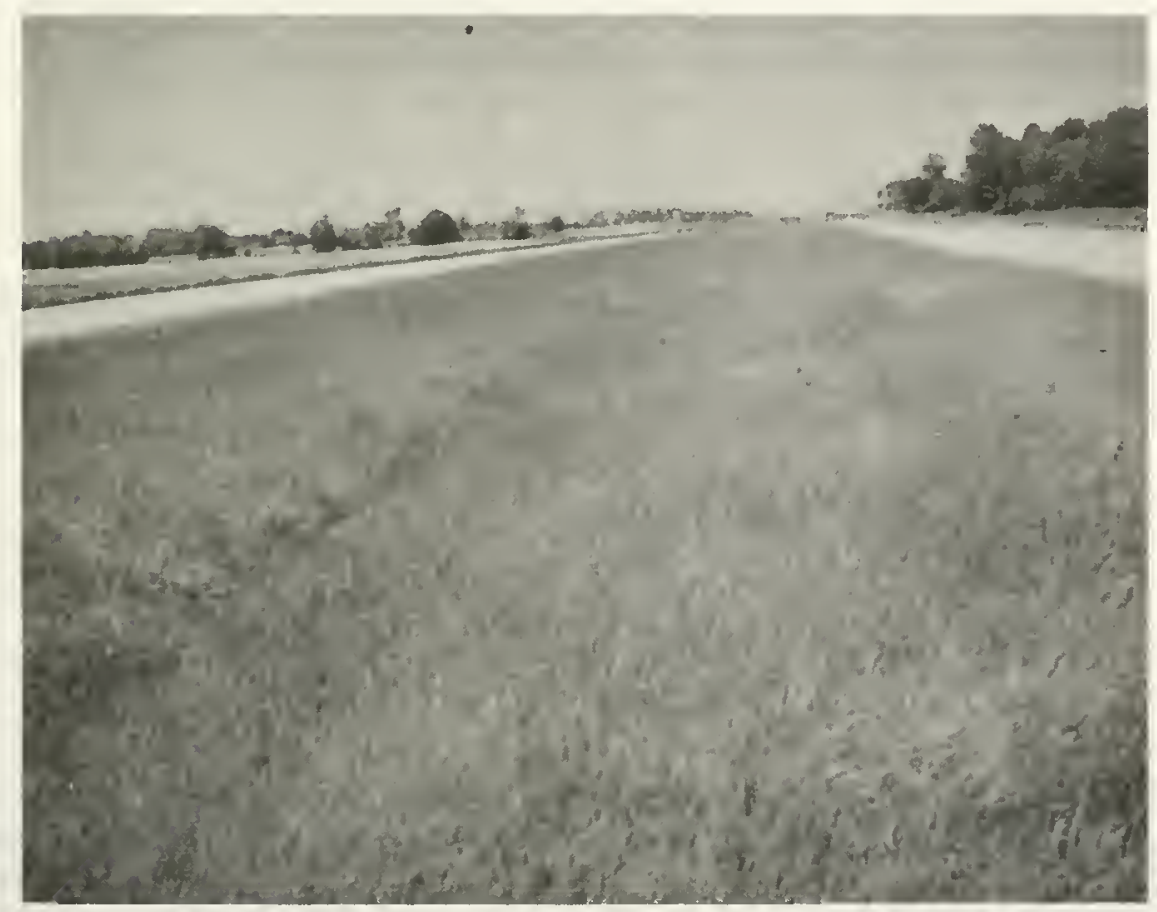

Figure 4. Sprayed median of I-69 near the Indiana-Michigan border. This portion received the fall-spring 2,4-D application cycle in the 1972-73 season in the Spraying Program by Contract (Table I). The area is essentially weed-free. Photographed June 2, 1973. 
An important advantage of fall applications of herbicides is that of environmental safety. In the fall, desirable plants in cropland or gardens, shrubs and flowers in lawns, golf courses, or recreational areas, and in roadside plantings and forests, are dying, dead or dormant. Trees and shrubs are losing their leaves, and unlike the plants to be controlled, escape the herbicide. Problems of drift onto soybean or tomato fields are eliminated since the growing season is over. By the following spring, soll residues are completely dissipated especially with the biodegradable herbicides such as 2,4-D.

Only non-toxic 2, 4-D amine formulations of herbicide are recommended.--The environmental safety of various roadside herbicides were evaluated in laboratory, greenhouse, and field investigations $(1,3,4)$. The potential hazard of pure 2,4-D to fish or algae fromterrestrial runoff water (concentrations of $0.1 \mathrm{ppm}$ or less) or direct or accidental contamination ( $31 \mathrm{~b} / \mathrm{acre}$ applied directly to 6 inches of water) is nil. Studies with formulated materials, however, showed that 2, 4-1) ester derivatives are substantially more toxic than the parent acid; fish and phytoplankton kills result at the $3 \mathrm{lb} /$ acre rate applied directly to water.

In June 1971, a recommendation was made to the Indiana State Highway Commission that only non-toxic amine and salt formulations of 2,4-D be used for roadside spraying, and that use of toxic ester formulations be discontinued. The recommendation was accepted and beginning in the fall of 1971, use of 2,4-D has been restricted to amine formulations (Table I).

A 3-year spraying rotation minimizes costs and maximizes effectiveness.-In 1971, approximately 1,500 linear miles of highway received a fall application of 2,4-D between September 15 and October 15 under the Spraying Program by Contract. Evaluations of test plots throughout the state showed the treatment to be extremely effective with weed control 2 months after treatment ranging from $85 \%$ to over $95 \%$ (Table II). The fall application was followed by a second application in early

\section{TABLE II}

CONTROL OF PERENNIAL WEED SPECIES BY FALL APPLICATIONS OF 2.7 LB/A 2,4-D. The 2,4-D was applied using conventional truck-mounted equipment by Chemitrol, a contractual herbicide applicator. Applications were on October 4, 1971 with evaluations on December 4, 1971.

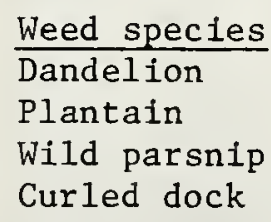

\begin{tabular}{cr} 
Plants/100 square feet \\
\hline Check & $\frac{2,4-D}{71}$ \\
\hline 588 & 3 \\
155 & 0 \\
211 & 0 \\
19 &
\end{tabular}

spring (Table I). The spring application was to control:seedlings and new growth which escaped the fall application. It too, was effective and environmentally safe. The spring application was scheduled sufficiently early to avold crops and at a time when most trees and-shrubs were still in a dormant or near-dormant condition. The combined spring and fall applications were sufficiently effective to eliminate all mid-summer chemical treatments (Figs. 1-4). Th1s was advantageous from an environmental standpoint since the midsummer treatments were those most 1 ikely to cause injury to non-target vegetation. The direct cost saving to the State of Indiana from the Herbicide Treatment Program by Contract alone was an estimated $\$ 60,000$ annually. This figure is based on the difference in cost between the standard 3 applications of herbicide in spring and mid-summer used prior to 1971 and the 3-year rotation implemented in 1971. Not included are benefits from increased weed control, safety, or reduced mowing costs. 


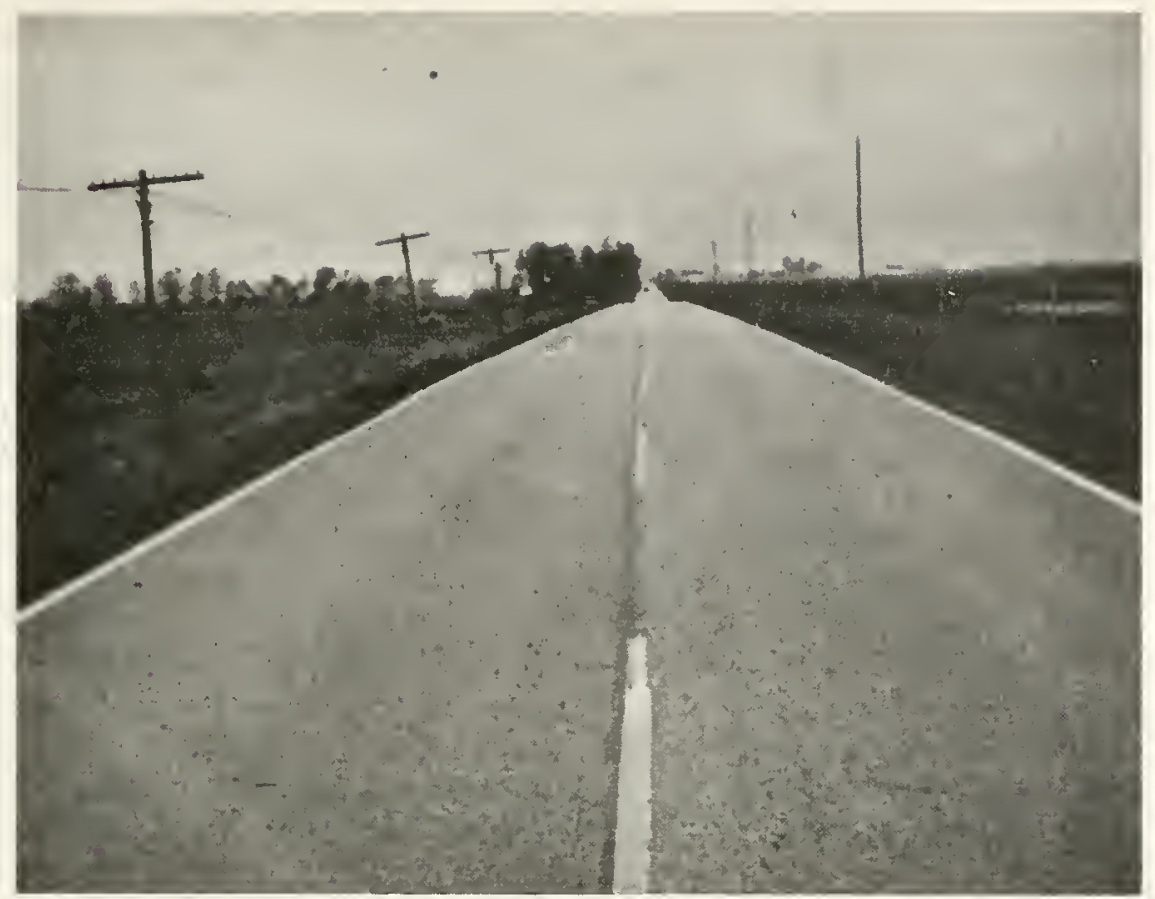

Figure 5. Portion of U.S. 421 north of Lafayette, Indiana, in White County. The right side of the road received a single fall application of an experimental formulation (M-3766) containing 3 parts picloram and 1 part 2,4-D at a rate of 2 lbs active ingredient per acre. The left side of the road was unsprayed. Photographed in the spring following application.

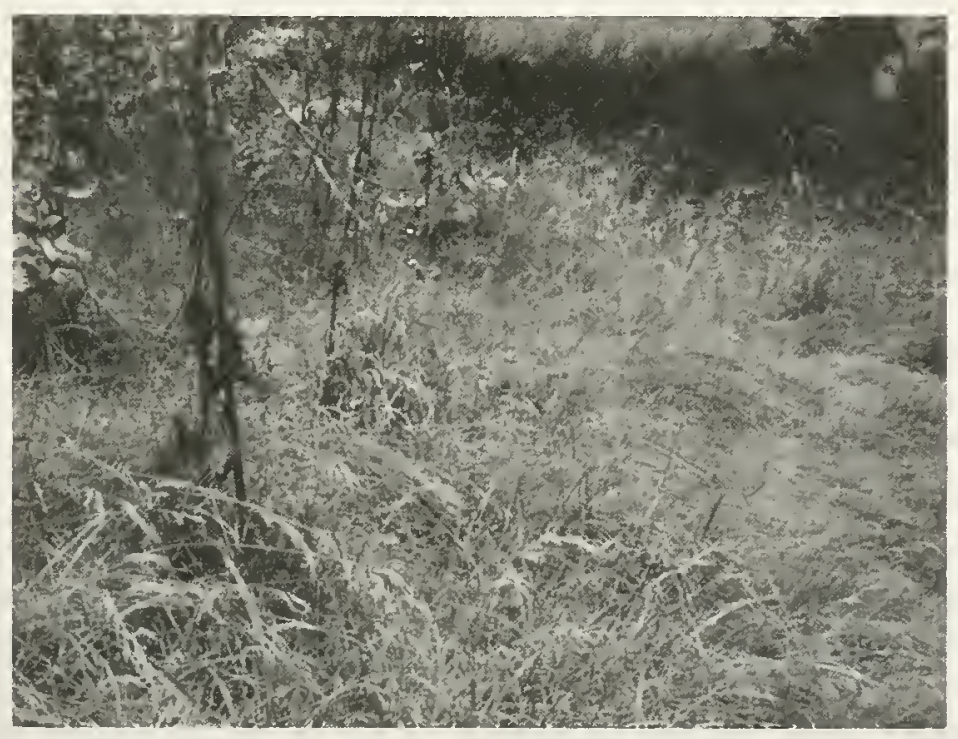

Figure 6. Wild parsnip plots on July 25, 1972 approximately 2 years after treatment with a mixture of $3 / 41 \mathrm{~b}$ per acre of picloram plus $1 / 41 \mathrm{~b}$ per acre of 2,4-D. The unsprayed area is on the left and shows numerous plants of wild parsnip 4 to 5 feet high which have matured and produced seed. The treated area is on the right and is free of weeds. 
The concept of a 3-year rotation stemmed from data summarized in Figure 7. These data are from the 1971 spraying program one year after spraying. The lower curve represents roads which had been sprayed in previous years and contained mostly resistant species. The upper curve represents roads which had not been sprayed recently and contained mostly 2,4-D susceptible species.

A pattern of weed control emerged as follows: The optimum weed density for maximum effectiveness was about 150,000 weeds per acre. With this weed density, control approached $90 \%$ on roads not previously sprayed. As the weed density decreased or increased from this value, effectiveness of weed control decreased. With roads having 25,000 weeds per acre or less, treatment effectiveness ranged from 0 to $30 \%$. These roads were not "weedy" to begin with, contained mostly 2, 4-D resistant species, and should never have been sprayed in a contract program.

Based on the above data and results from experimental plots, a 3-year spraying rotation was established for the entire State of Indiana. The roads were divided into three groups of about 4,000 linear miles (24,000 acres) each. Group A was the Interstate System. Groups $B$ and $C$ were composed of roads of the State Highway System. Roads of group A received a fall-spring 2,4-D cycle in 1972-73 (F1gs. 2 and 4). Roads of group $B$ are receiving a fall-ospring cycle in 1973-74 and roads of group $C$ will receive a fall-spring 2,4-D cycle in 1974-75. In the fall of 1975, the cycle will be repeated beginning with roads in group A. The program is computerized to reduce administrative costs. Mr. Marion Bugh, Landscape Supervisor, Indiana Highway Commission and his staff did an excellent job in setting up the contracts so that each year approximately $1 / 3$ of the state is sprayed with maximum efficiency for both the State and the Individual contractors.

We anticipate that by the fall of 1975 roads in group A will have weed densities in the range of 75,000 to 150,000 weeds per acre so that the cycle will be repeated. One year after spraying, the weed density is about 15,000 weeds per acre. To spray these roads then would be a waste of time and money. Two years after spraying, we forecast the weed density to be 30,000 to 50,000 weeds per acre. At best, we could expect $50 \%$ control to reduce the population back to 15,000 weeds per acre. By three years, when the weed population has again reached the 75,000 to 150,000 weeds per acre level, the roads will be resprayed.

Some experimental herbicide mixtures give a weed-free turf for 3 years following a single fall application.--What about 2,4-D-resistant weed species? Will they eventually increase to the point that 2,4-D-spraying becomes ineffective? We do not have answers to these questions but are exploring new and more potent herbicide mixtures for use along Indiana roadsides if and when they are needed. By using more potent herbicides, we have maintained turf in a near weed-free conditions for at least 3 years following a single fall application (Figs. 8-10) with no injury to grass or trees. Therefore, only one application every 3 years is required. Even the spring application is eliminated; an additional cost saving feature.

One of these herbicide mixtures, currently under intensive investigation, consists of a combination of three parts of picloram (trade name Tordon) and one part of 2,4-D plus an agent to control drift. The picloram-2,4-D combination is a potent herbicide for control of a wide range of broad-leaved herbaceous and woody roadside vegetation. Difficult-to-control perennial species such as common milkweed and Canadian thistle are especially susceptible to picloram. A significant portion of the picloram necessary for control of these species is replaced by the less-expensive phenoxy herbicides such as 2,4-D without reducing the overall effectiveness of the treatment $(1,2)$.

With the objective of testing the possibility of a 3-year spraying rotation in which one herbicide treatment would keep the roadsides free of weeds for the entire 3-year perfod, plots were established in the falls of 1970, 1971, 1972, and 1973 to evaluate the lasting effectiveness of combination treatments, and in 1972 


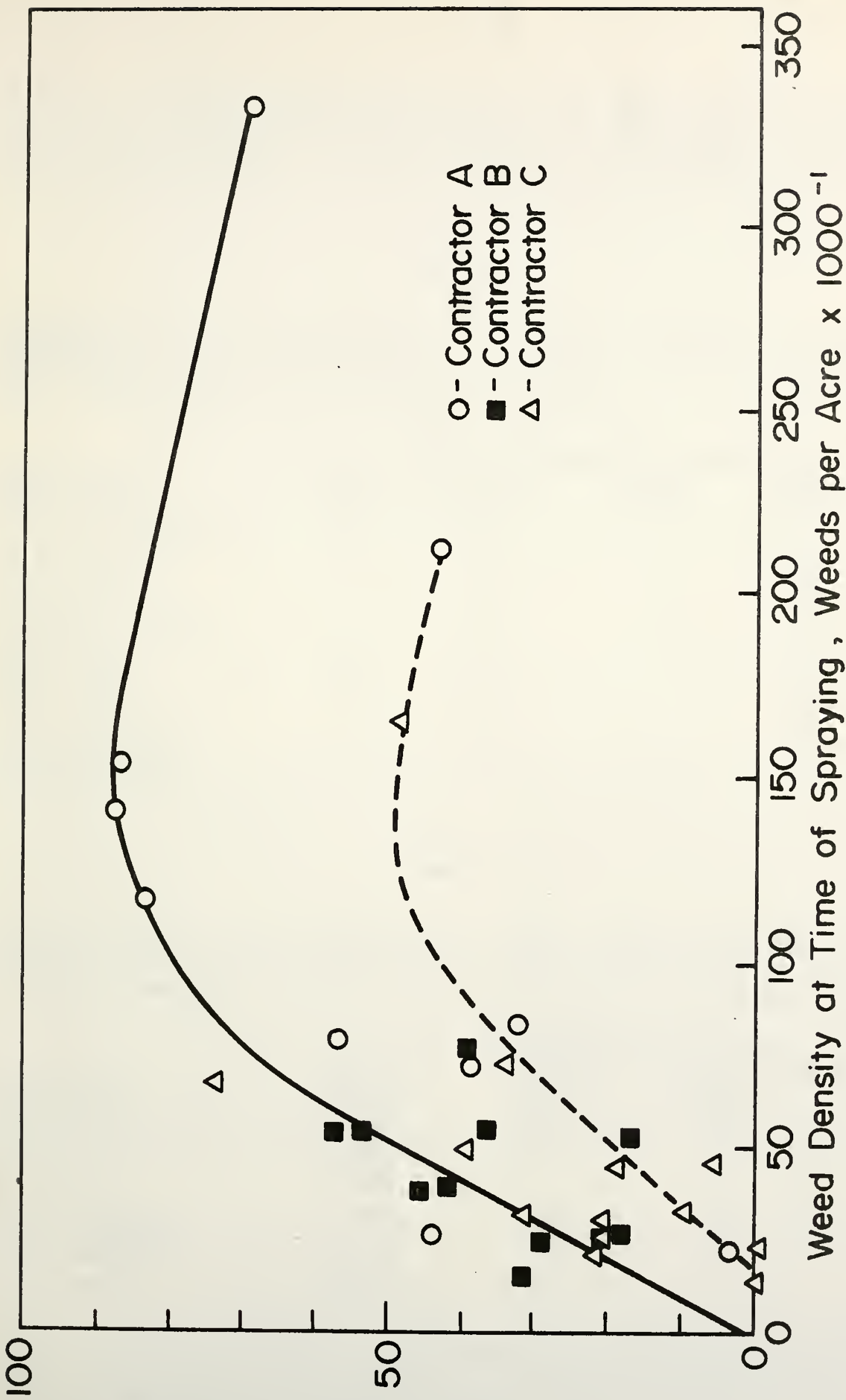

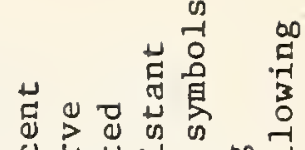
U ป 仓 . 1 मे बत् क्ष

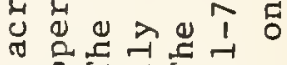

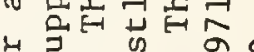
r. ज a $N$

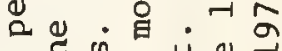

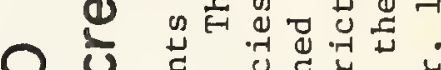
茫: 仓 क क क स (1) 2. थ

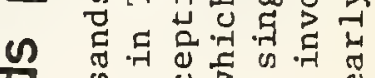
O थ ए 3 כ व

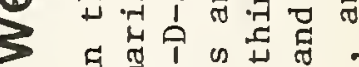

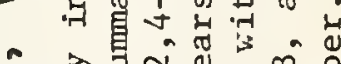
(2) 出 E थै ब ते

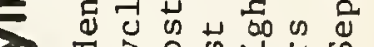

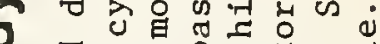

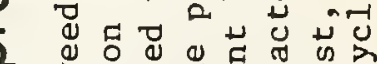

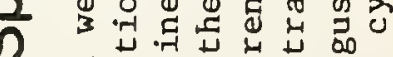
동

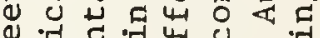

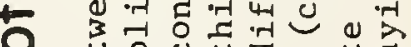

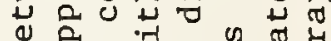
ڤ

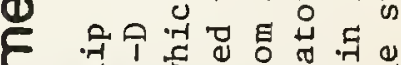

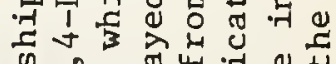
¿ैं . 0 䨔 (1) यू की

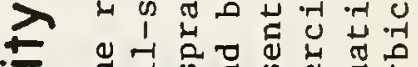

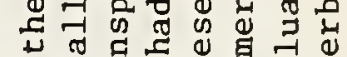

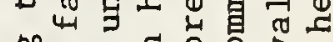

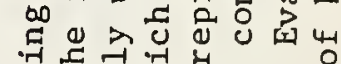

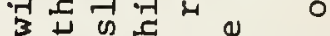
उั ल 대 \ 대언

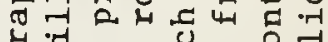

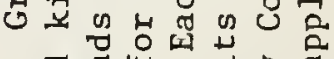

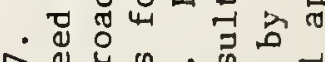

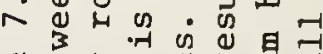
ब 尚

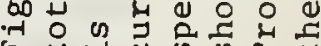

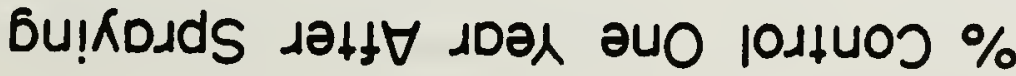


and 1973 to evaluate environmental safety. Triplicate plots were sprayed at rates of $\frac{1}{2}, 1,1 \frac{1}{2}$, and $2 \mathrm{lb} / \mathrm{acre}$ (up to $6 \mathrm{lb} / \mathrm{acre}$ in the environmental tests) in midAugust to early October. All species were 90 to $100 \%$ controlled the first season by applications at rates of 1 1b/acre or greater (Table III, Table IV). Evaluations

TABLE III

EFFECTIVENESS OF A FALL APPLICATION OF PICLORAM (3 parts) PLUS 2,4-D (1 part) MIXTURES ON CONTROL OF ROADSIDE WEEDS IN THR SEASON FOLLOWING APPLICATION.

The treatments were applied in m1d-August 1970 and counts were taken October 7 , 1971. Data are given in plants per 100 square feet.

\begin{tabular}{lr} 
Weed species & Check \\
\cline { 2 - 2 } Wild carrot & 119 \\
Buckhorn planta1n & 6 \\
Rough cinquefoll & 3 \\
Common milkweed & 1 \\
W1ld parsnip & 8 \\
Broadleaf plantain & 3 \\
Whorled milkweed & 12 \\
Black medic & 10 \\
White clover & 5 \\
Yellow woodsorrel & 29 \\
Nodding spurge & 6 \\
Composite family & \\
(Golden rod, asters, etc.) &
\end{tabular}

Rate of application of total herbicide mixture

\begin{tabular}{c}
$\frac{1 / 2}{2} \mathrm{lb} / \mathrm{A}$ \\
\hline 2 \\
1 \\
0 \\
0 \\
0 \\
0 \\
0 \\
0 \\
0 \\
0 \\
9 \\
0
\end{tabular}

\begin{tabular}{cc}
$1 \frac{1}{2} 1 \mathrm{~b} / \mathrm{A}$ & $2 \frac{1 \mathrm{~b} / \mathrm{A}}{0}$ \\
\hline 0 & 0 \\
0 & 0 \\
0 & 0 \\
0 & 0 \\
0 & 0 \\
0 & 0 \\
0 & 0 \\
0 & 0 \\
0 & 0 \\
0 & 0 \\
9 & 9 \\
0 & 0
\end{tabular}

TABLE IV

EFFECTIVENESS OF A FALL APPLICATION OF PICLORAM (3 parts) plus 2,4-D (1 part) MIXTURE ON CONTROL OF ROADSIDE WEEDS. Treatments were applied in early October 1972 with commerclal truck-mounted equipment and counts were taken in May 1973.

\section{Weed species}

Planta1n

Dandelion

Wild carrot

Clovers

Curled dock

Common thistle

Other composites

Other weeds
Plants/acre, May 1973

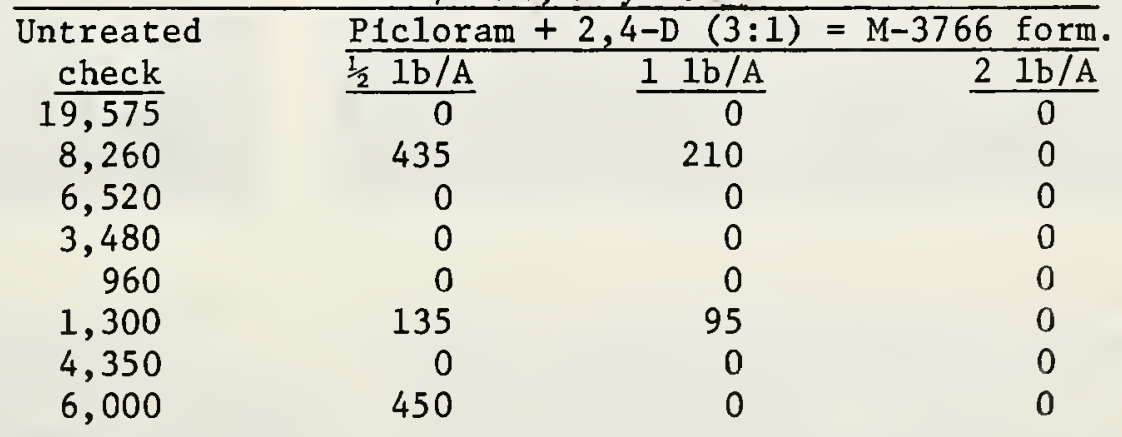

one and two years later indicated lasting control for most specles except a few summer annuals such as nodding spurge which germinate from seed in early summer and are not especlally objectionable. For all practical purposes, the sprayed plots were st111 weed free (F1gs. 9 and 10) at the 2 lb/acre rate 3 years after spraying with the experiment begun in 1970 . 
In the 1972 study, the environmental safety of picloram was evaluated. Based on extensive laboratory, greenhouse, and fleld testing (1, 2, 3, 4), a 3:1 ratio of picloram plus 2,4-D was selected for inttial evaluation under roadside conditions at a rate of $1 \mathrm{lb} / \mathrm{A}$ of total herbicide ( $3 / 4 \mathrm{lb}$ picloram plus $1 / 4$ b 2,4-D amine). The application used truck-mounted equipment supplied by Chemitrol, Indianapolis, Indiana, and was in early october. The formulation, designated M-3766, was provided by Dow Chemical Company, Midland, Michigan, according to our specifications. It contained $1 \frac{1}{2} 1 \mathrm{~b}$ a.i. picloram plus $\frac{1}{2} 1 \mathrm{~b}$ a.1. 2,4-D per gallon as the triisopropanolamine salts. Applications were at rates of $\frac{1}{2}, 1,2$, and $61 \mathrm{~b} /$ acre a.1. Endrift, a drift-reducing agent commerclally avallable and manufactured by Nalco Chemical Company, was included at the rate of 1 quart per 100 gallons of spray in all applications. Drift tests showed a 40 to $50 \%$ reduction in the amount of herbicide reaching non-target areas using this material. Included in the test were roadside plantings, ornamental plantings, hardwood forest, conifers, a flowing stream, and cropland. Species composition were determined and soll and water samples were collected prior to and after spraying. At 1 1b/acre, M-3766 gave $90 \%+$ control of all species Including Canadian thistle and the 2 lb/acre rate gave complete control of all weed species (Table 4, Fig. 5).

Using a sensitive blological assay procedure developed under this profect, testing of water samples, collected from the stream running through one of the test sites, revealed no detectable herbicide entering the water from drift (at the time of spraying). Tests of soll samples showed that the herbicide remained on the target area except for one situation at the $6 \mathrm{lb} / \mathrm{acre}$ rate where the sprayed roadside was higher than the adjacent field and where the drainage ditch channeled soll and water from approximately $1 \mathrm{mile}$ of road directly into one spot of the fleld. Here, herbicide entered the fleld and caused slight injury to soybeans. Examination of roadside plantings, native vegetation, and fruit trees in an orchard adjacent to the sprayed roadside revealed no damage to spectes not oversprayed directly.

A simflar test, although not as extensive, was established in the spring of 1973, with M-3766 applied at a rate of 2 1b/acre. In this test, basswood trees adjacent to the sprayed roadside were killed. Other tree specles showed only minor injury symptoms including those in which root systems were directly oversprayed and a11 survived. In spite of heavy rains, soll movement of no more than 3 feet was experienced. However, picloram will not be recommended for use in spring or summer applications for general roadside weed control because of possible crop injury.

Picloram, which has a mode of action similar to that of 2,4-D (5) has proven non-toxic in pure form $(3,4)$. Laboratory tests of the formulated material are nearing completion and show no injury to fish or algae which might result from normal use practices.

A third herbicide combination involving dicamba (Banvel) plus 2,4-D also looks promising in preliminary tests to control 2,4-D-resistant spectes. This material is not as effective as the picloram plus 2,4-D combination but is expected to provide a greater margin of environmental safety.

Reduced mowing costs are an added benefit.--Effective programs of herbicide treatment reduce the number of required roadside mowings. With the weed control provided by the 3-year rotation (with elther 2,4-D amine alone or with the more potent mixtures), 3-cycle mowing (once in late spring, once in mid-aummer, and once in late summer or early $\mathrm{fall}$ ) is sufficient. The reduction in the number of mowing cycles (from 4 or 5 to 3 ) adds an additional $\$ 100,000$ annual cost saving to the program (based on figures provided by Mr. Marion Bugh, Landscape Supervisor, Indiana State Highway Comnission).

Further reductions in mowing cycles (less than 3) may not be feasable. Onecycle mowing, or even two-cycle mowing, if scheduled early leaves too much growth 
in the fall for effective applications of herbicides. If scheduled later, the tall grass which is mowed and not raked smothers the underlying sod. Large bare spots subject to erosion are the result. It may prove more advantageous to not mow at all than to mow only once or twice.

In summary, rights-of-ways are designed for safety and convenience. They should be kept as corridors of open turfed areas to provide the features of safety, beauty, and convenience for which they were intended. To maintain a healthy turf, maintenance of these areas by mechanical and chemical methods must continue. Our findings show new ways of providing such maintenance at low cost to the state and minimum danger to the environment.

\section{Literature cited.}

1. D. J. Morré and D. A. Werderitsh, "Chemical Weed Control, Final Summary Report, Part III. Research in Roadside Development and Maintenance", Joint Highway Research Report, Purdue University and Indiana State Highway Commission, Number 24, 102 pp. (July 197.2).

2. S. Krawiec and D. J. Morré, "Interactions of Tordon Herbicide Applied in Combinations", Down to Earth 24(3): 7-10 (Winter 1968).

3. M. Sergeant, D. Blazek, J. H. Elder, C. A. Lembi and D. J. Morré, "The Toxicity of 2,4-D and Plcloram Herbicides to F1sh", Proceedings Indiana Academy of Science for 1970 80: 114-123 (1971)

4. J. H. Elder, C. A. Lembi and D. J. Morré, "Toxicity of 2,4-D and Picloram to Fresh and Salt Water Algae", Proceedings North Central Weed Control Conference 25: 96-98 (1970).

5. W. R. Elsinger and D. J. Morré, "Growth-Regulating Properties of Picloram, 4-Amino-3,5,6-Trichloropicolinic Acid", Canadian Journal of Botany 49: 889897 (1971). 
TECHNICAL REPORT STANDARD TITLE PAGE

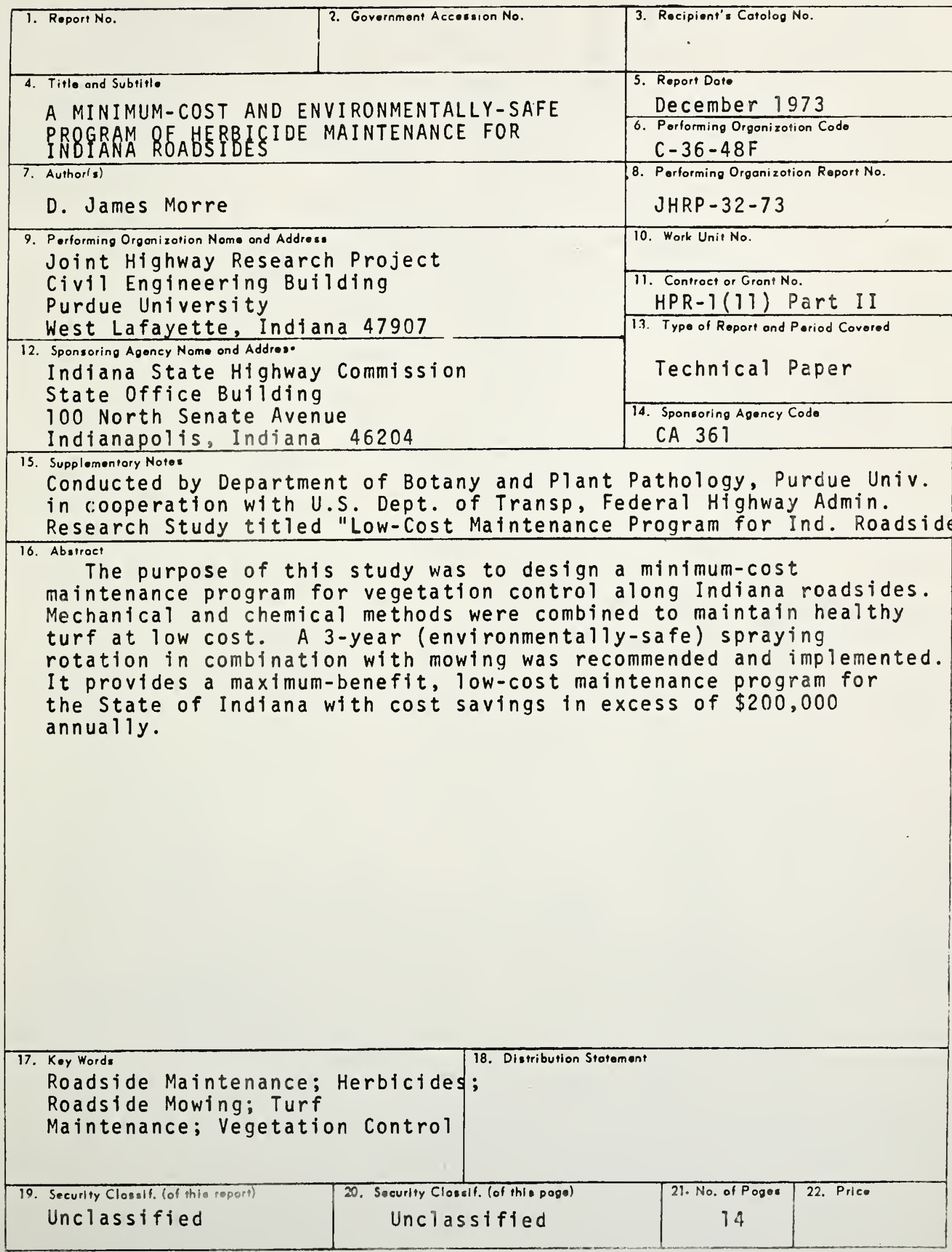





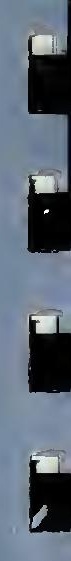

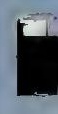

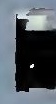

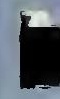

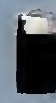

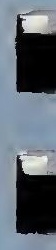

-

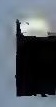

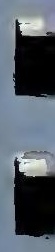

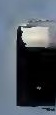

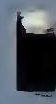

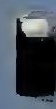

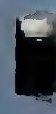

10 